\title{
Hypolimnetic withdrawal coupled with oxygenation as lake restoration measures: the successful case of Lake Varese (Italy)
}

\author{
G. Premazzi ${ }^{1}$, A. C. Cardoso ${ }^{1}$, E. Rodari ${ }^{1}$, M. Austoni ${ }^{1}$ and G. Chiaudani ${ }^{2}$ \\ ${ }^{1}$ European Commission, Joint Research Centre, Institute for Environment and Sustainability, JRC-Ispra, 21020 \\ Ispra, Italy. \\ E-mail: guido.premazzi@jrc.it ; ana-cristina.cardoso@jrc.it \\ ${ }^{2}$ Department of Biology, University of Milan, 20100 Milan, Italy.
}

\begin{abstract}
Lake Varese is a relatively small lake, belonging to the drainage basin of lake Maggiore (northern Italy). It has had a long history (since 1960s) of water quality deterioration as the result of cultural eutrophication. In 1967 a restoration project was designed, including a sewerage network, an O-ring sewage diversion system, and a centralised wastewater treatment plant with phosphorus and nitrogen control. Since the 1990's, the lake has been the object of a cooperative research program supported by the European Commission, the Italian Ministry of the Environment, the Lombardy Region, and the Varese Province. The subsequent studies revealed that the lake responded to the decreased external nutrient loads. Besides, mathematical models predicted a rather long period (30 years) to attain the restoration goal, recognising the importance of internal P loading from sediments. Also, it was predicted that the application of in-lake measures would be beneficial in accelerating lake recovery. Recently, two measures have been suggested, i.e. hypolimnetic withdrawal in the deepest section (maximum depth: $26 \mathrm{~m}$ ) and oxygenation in the shallower section, during summer stratification. Lake Varese constitutes the first case in Italy where in-lake methods are used to counteract the problems caused by excessive nutrient enrichment in a relative large system (lake surface: $\left.14.52 \mathrm{~km}^{2}\right)$. In this paper, preliminary results of the first two years of operation (2000/2001) are summarised. The results are greatly encouraging. Lake water quality characteristics are as follows: Secchi transparency increased from $3.2 \mathrm{~m}$ to $4.9 \mathrm{~m}$; annual mean total P concentrations decreased from $180 \mathrm{mg} / \mathrm{m}^{3}$ to $70 \mathrm{mg} / \mathrm{m}^{3}$; average chlorophyll values decreased from $40 \mathrm{mg} / \mathrm{m}^{3}$ to $17 \mathrm{mg} / \mathrm{m}^{3}$; the frequency of nuisance algal blooms declined to half in comparison to the 1990's and the algal density declined by a factor of 4 , and anoxia periods decreased in time and space. Moreover, it has been evaluated that nutrient loads from lake Varese, due to the selected water discharges, did not affect the total nutrient budget of lake Maggiore and the downstream water quality.
\end{abstract}

Keywords: eutrophication, lake restoration, in-lake measures, recovery time

\section{RESUMEN}

El lago Varese es un lago relativamente pequeño, situado en la cuenca de drenaje del lago Maggiore (norte de Italia). Presenta una larga historia (desde los años 60) de degradación de la calidad del agua como resultado de una eutrofización cultural. En 1967 se diseñó un proyecto de restauración, incluyendo una red de alcantarillado, un sistema en anillo de desvío de aguas residuales, y una planta centralizada de tratamiento de aguas residuales con control de fósforo y nitrógeno. Desde los años 90 , el lago ha sido objeto de un programa de cooperación científica financiado por la Comisión Europea, el Ministerio de Medio Ambiente de Italia, la Región de Lombardy y la provincia de Varese. Los estudios resultantes mostraron la respuesta del lago a la disminución de la carga de nutrientes externa. Además, los modelos matemáticos predijeron un período bastante largo (30 años) para lograr el objetivo de restauración, reconociendo la importancia de la carga interna de P de los sedimentos. También, se predijo que la aplicación de medidas en el propio lago sería beneficiosa en la aceleración de la recuperación del lago. Recientemente, se han propuesto dos medidas, i.e. drenaje hipolimnético en la cubeta más profunda (profundidad máxima: $26 \mathrm{~m}$ ) y oxigenación en la zona más somera, durante la estratificación estival. El lago Varese constituye el primer caso en Italia donde se han adoptado medidas en el propio lago para contrarrestar los problemas causados por un enriquecimiento excesivo de nutrientes en un sistema relativamente grande (superficie del lago: $14.52 \mathrm{~km}^{2}$ ). En este artículo se resumen los resultados preliminares de los dos primeros años de actuación (2000/2001). Los resultados son enormemente alentadores. Las características de la calidad del agua del lago son las siguientes: la transparencia del Secchi aumentó de 3.2 a 4.9 m; las concentraciones medias anuales de P total disminuyeron de $180 \mathrm{mg} / \mathrm{m}^{3}$ a $70 \mathrm{mg} / \mathrm{m}^{3}$; los valores medios de clorofila disminuyeron 
de $40 \mathrm{mg} / \mathrm{m}^{3}$ a $17 \mathrm{mg} / \mathrm{m}^{3}$; la frecuencia de florecimiento de algas se redujo a la mitad en comparación con los años 90 y la densidad de algas se dividió por un factor de 4, y los periodos de anoxia disminuyeron en el tiempo y en el espacio. Además, se ha comprobado que la carga de nutrientes procedente del lago Varese, a causa de las descargas de agua selectivas, no afectó al balance total de nutrientes del lago Maggiore ni a la calidad del agua del río aguas abajo.

Palabras clave: eutrofización, restauración de lagos, medidas in-situ, tiempo de recuperación

\section{INTRODUCTION}

Lake Varese was the first case in Italy to experience problems of cultural eutrophication. The main problems being (i) the anoxic conditions in hypolimnetic waters; (ii) the intense algae blooms with toxin producing species and excessive macrophyte presence; (iii) the significant P loadings from sediment; (iv) the frequent fish kills, and (v) the hindering of water uses, except fishing and navigation.

The deteriorating water quality was reported in the press and the scientific community addressed the related issues. By 1965 public concern had resulted in initiatives to form a local agency (Consorzio Volontario di Tutela e Risanamento delle Acque) to address the problem of the lake management. In 1967, a restoration plan was promoted by the action of the Varese Province with the adoption of measures to reduce the external nutrient loads. These measures included a (i) sewage collection network, (ii) an O-ring diversion system, and (iii) a centralised wastewater treatment plant (Fig. 1). Wastewaters received tertiary treatment in 1986 and diversion was completed in 1994.

According to the Regional Water Clean-UpPlan (1992) the objectives for this lake are: (a) to protect the aquatic biota, (b) to achieve a good ecological status, and (c) to safeguard the water uses including drinking water supply, bathing, fishing and irrigation. This plan established quantitative objectives to be attained for the total phosphorus (about $30 \mathrm{mg} / \mathrm{m}^{3}$ ) and dissolved oxygen concentrations ( $\geqslant 4 \mathrm{mg} \mathrm{O}_{2} / \mathrm{l}$ ).

Since the 1990's, the lake was the object of a cooperative research program among the European Commission, the Italian Ministry of the Environment, the Lombardy Region, and the Varese Province (Premazzi et al., 1995). The subsequent studies, aiming to assess the environmental benefits of the planned restoration program, evaluated the recent evolution of the lake's trophic status and estimated a nutrient mass balance. It was concluded that a reduction of external nutrient loads alone was not sufficient to attain the planned restoration goals due to the significant nutrient loading from sediments (Rossi \& Premazzi, 1991; Premazzi, 1994; Premazzi et al., 1995).

Rossi \& Premazzi (1991) have developed a simplified model of the lake-sediment system aiming to predict the long-term evolution and recovery time of eutrophicated lakes, where direct application of the OECD load-response relationship to estimate the recovery time is not a general rule. This model was applied to lake Varese to make more realistic predictions on the recovery time. It was predicted that a rather long period (about 30 years) should be required to attain the restoration goal. Thus, the suitability and feasibility of different in-lake restoration techniques were evaluated to counteract the effect of the internal nutrient loading to shorten the recovery time. Two in-lake restoration measures have been proposed, i.e. hypolimnetic withdrawal and oxygenation. Oxygenation was indicated to guarantee proper dissolved oxygen concentrations to the biota in the shallower sections of the lake (Premazzi, 1994). The plan was ready to start in the spring of 2000.

This paper reports a preliminary appraisal of the first two years (2000 and 2001) of the functioning of in-lake restoration measures, illustrating the general improvement of the lake trophic conditions. 


\section{STUDY SITE}

Lake Varese is a relatively small insubrian lake, belonging to the drainage basin of lake Maggiore (northern Italy). The lake is monomictic and stratified from May to October/November. The main morphometric and hydrological characteristics are summarised in Table 1. The lake basin can be divided into three sub-basins: Schiranna (maximum depth: $7 \mathrm{~m}$ ), Cassinetta (maximum depth:5m) and Gavirate (maximum depth: 26m).

Table 1. Main morphometric and hydrological characteristics of lake Varese. Principales características morfométricas e hidrológicas del lago Varese.

Drainage area $\left(\mathrm{km}^{2}\right)$

Lake surface $\left(\mathrm{km}^{2}\right)$

Maximum depth (m)

Mean depth (m)

Lake volume $\left(\mathrm{x} 10^{6} \mathrm{~m}^{3}\right)$

Water outflow $\left(\mathrm{m}^{3} \mathrm{~s}^{-1}\right)$

Theoretical water renewal time (year)

Effective water residence time (year)
The main tributary of the lake is the Brabbia channel that drains the basin of lake Comabbio. It has only one outlet the river Bardello, located at the northern end of the lake, which is a tributary of lake Maggiore.

\section{IN-LAKE MEASURES}

Figure 2 shows the location of the devices for hypolimnetic withdrawal and oxygenation in lake Varese.

Hypolimnetic withdrawal is carried out from May to November, period during which the lake is stratified and, consequently, the anoxic sediment is a source of phosphorus to the water column. It is achieved using about seven kilometres of PEAD plastic tubing, $800 \mathrm{~mm}$ in diameter, in the deepest part of the lake. The water suction is carried out using 12 perforated pipes, 400 $\mathrm{mm}$ in diameter, connected to the main tubing (diameter ranging from 560 to $800 \mathrm{~mm}$ ), suspended $1.5 \mathrm{~m}$ above the lake bottom. All pipes are

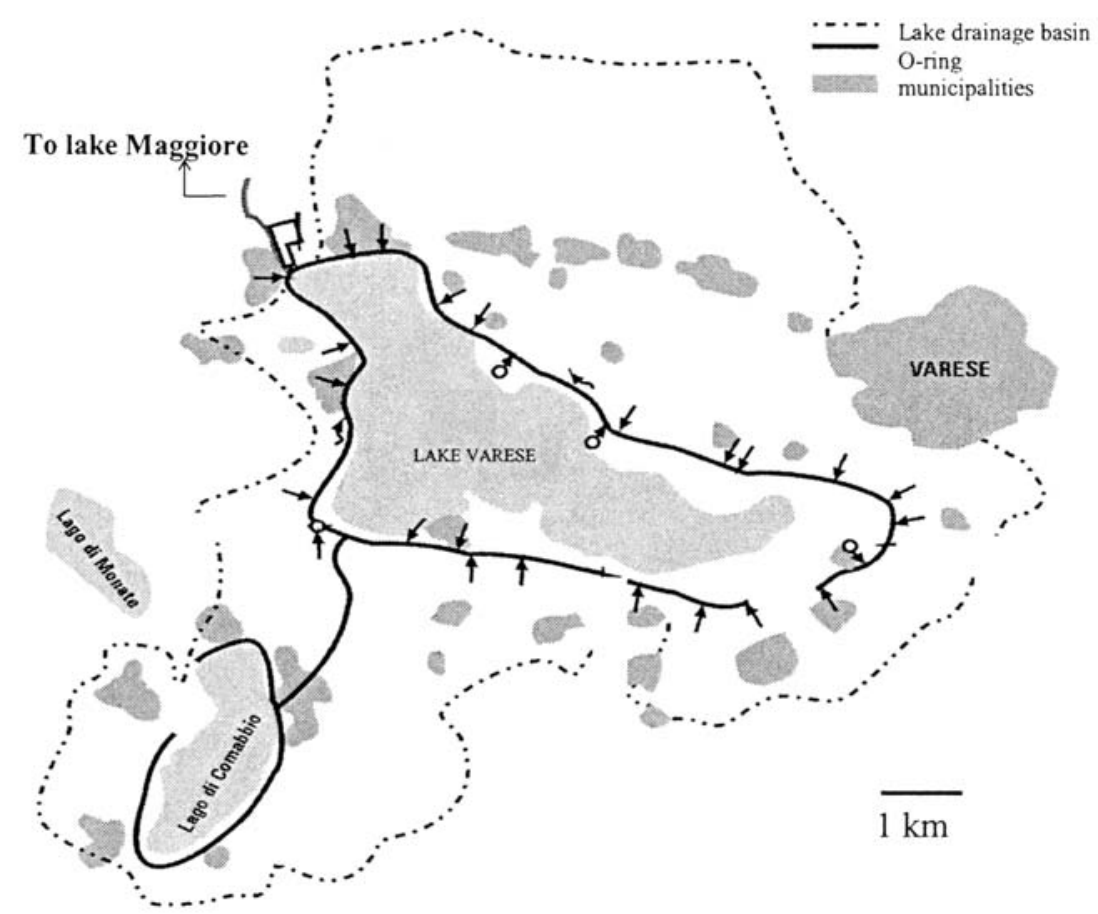

Figure 1. Restoration measures in the lake Varese catchment basin. Medidas de restauración en la cuenca de drenaje del lago Varese. 


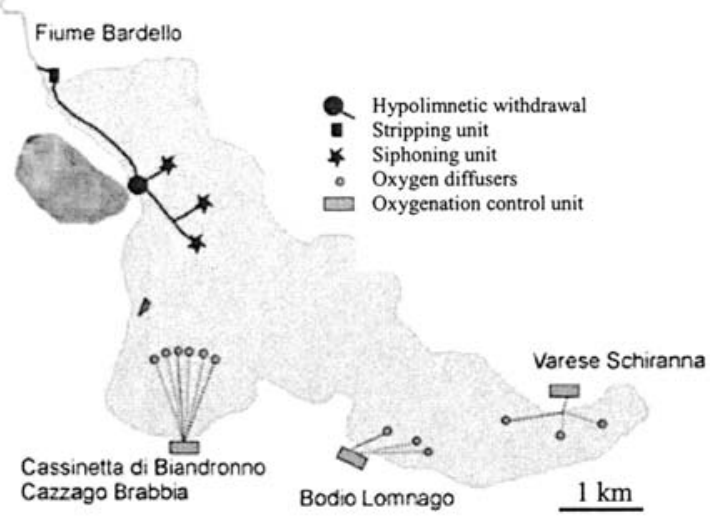

Figure 2. Location of in-lake restoration measures in lake Varese. Localización de las medidas de restauración en el lago Varese.

anchored on the lake bottom and operated to discharge (siphoning) deep waters without disrupting the water-sediment interface or creating water turbulence. The velocity of siphoned water was maintained below $3 \mathrm{~cm} / \mathrm{s}$ and the "suction field" was about $150 \mathrm{~m}^{2}$. The siphoned hypolimnetic water is treated in a stripping device with liquid oxygen, aiming to increase the DO level above 2-3 $\mathrm{mg} \mathrm{O}_{2} / 1$, to minimise the impact of reduced compound discharges (e.g. manganese, iron, sulphides) and to maintain safe concentrations of contaminants (e.g. ammonia) to the aquatic biota. Then, it is discharged to the river Bardello (the final receiving water body).

The deep-water discharge operates at a rate from 0.7 to $1 \mathrm{~m}^{3} / \mathrm{s}$. It was estimated that a total volume of 22 million $\mathrm{m}^{3}$ has been removed from the lake's bottom layer, out of a total volume of 8 million $\mathrm{m}^{3}$, in the past 2 years (306 days of functioning); in other words the deepest water layer has been replaced about 3 times in 10 months.

The aeration system consists of 12 special devices for the oxygen dissolution, based on the concept of first mixing gas/liquid with a Venturi type system and, secondly, mixing liquid/liquid with a system type ejectors/diffusers. The aerated water is discharged at a rate of $200 \mathrm{~m}^{3} / \mathrm{s}$, continuously from July to September in the shallower basins of the lake. The total daily transfer capacity of DO is $1 \mathrm{t} \mathrm{O}_{2}$ day $^{-1}$ device $^{-1}$. Liquid oxygen was supplied from a shore-mounted system (vaporisation of liquid to gas oxygen at room temperature, compressor) and it was introduced in the pipes through a diffuser. Four cryogenic tanks for the storage of liquid oxygen (temperature of $-183{ }^{\circ} \mathrm{C}$ ) are located in the shore stations. The oxygen diffusers are located at a distance of 500/600 $\mathrm{m}$ from the shoreline and to a depth varying from 5 to $10 \mathrm{~m}$. A total quantity of $1086 \mathrm{t}$ of oxygen was injected in the lake in the last two years (211 days of functioning).

Capital costs of both in-lake measures were about 4.3 $\mathrm{M}$ and operational costs were approximately $150 \mathrm{k}$ /year (mainly for oxygenation).

\section{MONITORING}

In the two years of the project a total of 175 sampling campaigns have been accomplished, corresponding to a total number of 1480 samples collected.

Lake Varese and river Bardello are monitored all year round on a monthly basis. Sampling is carried at the lake deepest point ( 8 depths) and in the two shallower basins, and in 6 stations along the river Bardello, from the outlet of lake Varese to lake Maggiore. Whereas, the hypolimnetic discharges are monitored twice a week during the period May- November.

Moreover, since April 2001 two limnological buoys have been installed in the Schiranna ( $5 \mathrm{~m}$ depth) and in the Gavirate basins (20 m depth), enabling the continuous automatic measurements of temperature, DO, oxygen saturation, conductivity and $\mathrm{pH}$.

Water transparency (Secchi depth), temperature, $\mathrm{pH}$, conductivity and alkalinity are recorded in situ, and samples in Winkler bottles fixed for dissolved oxygen determination. In the laboratory, several chemical and biological variables are determined: phosphorus (total $\mathrm{P}$ and soluble reactive $\mathrm{P}$ ) and nitrogen (total $\mathrm{N}$, nitrate, nitrite and ammonia) compounds, chlorophyll, dissolved oxygen, $\mathrm{BOD}_{5}, \mathrm{COD}$ and phytoplankton composition and abundance.

Nutrients were determined spectrophotometrically following the Standard Methods (APHA, 
1992). DO was determined following the modified Winkler method (IRSA, 1994). BOD $_{5}$ was determined following the modified Winkler method (IRSA, 1994). COD was determined following the method described in Jirka \& Carter (1975). Chlorophyll was determined with the cold methanol extraction method (Chiaudani \& Premazzi, 1999). Phytoplankton density was determined by counting the algae cells in sedimentation chambers using a Leitz inverted microscope. Cell biovolume was calculated either from already published data (Rott, 1981) or by measuring and calculating the cell volumes of the algae species in the sample. The algal cell volume was converted to fresh weightbiomass assuming a specific gravity of 1.0.

\section{RESULTS}

The evolution of $\mathrm{P}$ loads and total $\mathrm{P}$ concentrations of lake Varese, referring to 6 phases identified accordingly to the status of the restoration measures, is gathered in Table 2 (data pooled from Premazzi et al., 1995; Premazzi, 2002). It is seen that there is a marked decrease of lake $\mathrm{P}$ concentration correlated with the total $\mathrm{P}$ loading abatement, resulting from the restoration measures $(\mathrm{r}=0.905, \mathrm{df}=5, \mathrm{p}<0.01)$. In the years 1990 to 1997 the lake annual mean $\mathrm{P}$ concentration has decreased by $56 \%$ in association with the completion of the sewage diversion and starting of the tertiary treatment of waste-
Table 2. Evolution of external $\mathrm{P}$ loadings and mean annual $\mathrm{P}$ concentrations in lake Varese. Evolución de las cargas externas de P y concentraciones medias anuales de P en el lago Varese.

\begin{tabular}{|c|c|c|c|}
\hline Year & $\begin{array}{l}\text { P loading } \\
\text { (t P/ yr) }\end{array}$ & $\begin{array}{l}\text { P conc. } \\
\left(\mathrm{mg} / \mathrm{m}^{3}\right)\end{array}$ & $\begin{array}{l}\text { Protection and } \\
\text { restoration measures }\end{array}$ \\
\hline 1986 & 50 & 380 & ex-ante wwt and diversion \\
\hline 1990 & 25 & 320 & ex-ante diversion \\
\hline 1997 & 14 & 180 & ex-post wwt and diversion \\
\hline 1999 & $12-11$ & 130 & $\begin{array}{l}\text { ex-post wwt and diversion } \\
75 \% \text { of diffuse origin }\end{array}$ \\
\hline 2000 & $11-10$ & 95 & ex-post in-lake measures \\
\hline 2001 & $11-10$ & 70 & ex-post in-lake measures \\
\hline
\end{tabular}

water. In the following years, $\mathrm{P}$ loads to the lake reached the lowest values, considering that in $2000 \mathrm{P}$ loads from diffuse sources constituted about $75 \%$ of the total residual loading and, thus, difficult to be further intercepted. It represents no more than $18 \%$ of the total $\mathrm{P}$ load generated in the catchment basin. Nonetheless, it can be seen that the lake $\mathrm{P}$ concentration has significantly decreased in the years 2000 and 2001, in association with the hypolimnetic withdrawal. The amount of nutrients, exported from the lake by siphoning, increases along the stratification period (Table 3) as related to bottom oxygen conditions (Fig. 3).

The evolution of DO concentrations, and in particular of the anoxic bottom water layer show signs of improvement in the last years, as illustrate the time series of distribution of the

Table 3. Hypolimnetic withdrawal in lake Varese: nutrient budget for the years 2000/2001. Drenaje hipolimnético en el lago Varese: balance de nutrientes para los años 2000/2001.

\begin{tabular}{|c|c|c|c|c|c|c|}
\hline & \multicolumn{2}{|c|}{ Total P (kg) } & \multicolumn{2}{|c|}{ Total N (kg) } & \multicolumn{2}{|c|}{ Ammonia N (kg) } \\
\hline & 2000 & 2001 & 2000 & 2001 & 2000 & 2001 \\
\hline May & 302 & - & 2755 & - & 700 & - \\
\hline June & 409 & 322 & 3316 & 2201 & 1557 & 1914 \\
\hline July & 951 & 810 & 5417 & 5768 & 4100 & 4817 \\
\hline August & 1278 & 294 & 8008 & 2256 & 4138 & 2021 \\
\hline September & 1236 & 1179 & 7976 & 8622 & 5179 & 8151 \\
\hline October & - & 1397 & - & 13530 & - & 13139 \\
\hline November & - & 1027 & - & 9733 & - & 9471 \\
\hline Total & 4176 & 5029 & 27472 & 42110 & 15674 & 39513 \\
\hline
\end{tabular}


DO concentration in time (monthly) and in space (lake depth). It can be seen in figure 3 that from 1957 until 1999 there was a progressive reduction of the volume (lessening both the time and thickness, meaning number of months and depth limit) of surface water with DO concentrations more than $10 \mathrm{mg} \mathrm{O} / 1$. At the same time, an increase in the volume (augmentation of both the time and thickness, number of months and depth limit) of the bottom water layer with DO concentration of less than $0.3 \mathrm{mg}$ $\mathrm{O}_{2} / 1$ was observed, despite the measures introduced in the lake catchment for interception (i.e O-ring sewage diversion system completed in 1994) and abatement of nutrient loading (i.e. waste water treatment plant completed in 1988). The worse conditions in lake Varese were registered in 1999 when oxygen isoplets reached the

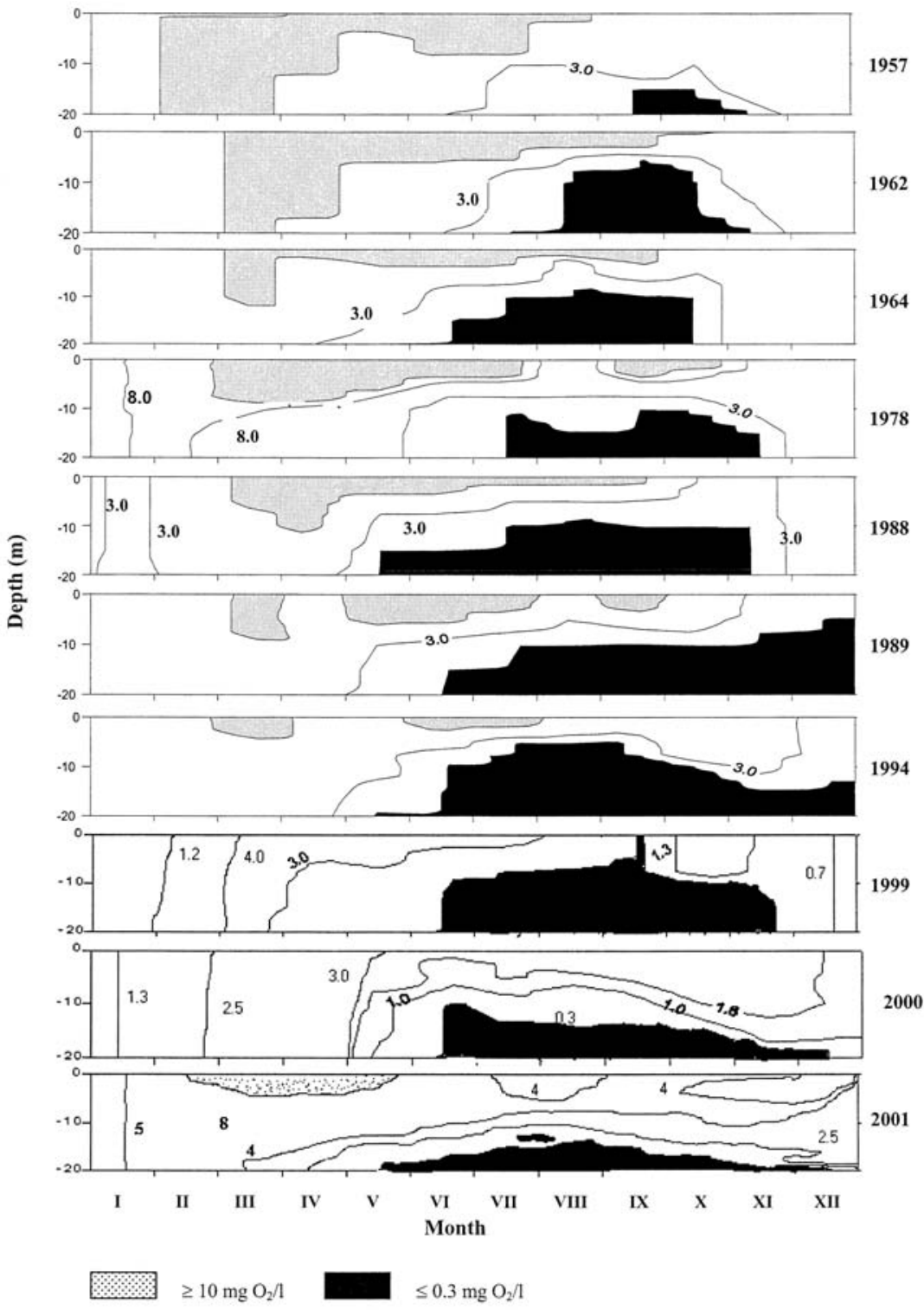

Figure 3. Time series evolution of dissolved oxygen concentration in lake Varese. Evolución de las series temporales de la concentración de oxígeno disuelto en el lago Varese. 
lowest values during the winter circulation (around $1 \mathrm{mg} / \mathrm{l}$ ), showing a significant resilience (ca. five years) to recovery processes. This trend has reversed in the last two years (2000 and 2001), when the volume of the bottom anoxic layer has started to decrease, and in 2001 surface water with a DO concentration higher than $10 \mathrm{mg} \mathrm{O}_{2} / 1$ is recorded again. The last year improvement would combine the effects of previous nutrient reductions in the catchment basin and the in-lake restoration measures.

The record of bloom events during the last decades presents further positive evidence of the lake's recovery (Table 4). The frequency has decreased steadily, with the exception of 1994, from 8 to 3 algae blooms per year. In the same period, algal density declined by a factor of 4 and chlorophyll decreased from $40 \mathrm{mg} / \mathrm{m}^{3}$ to $17 \mathrm{mg} / \mathrm{m}^{3}$. Secchi transparency increased from $3.2 \mathrm{~m}$ to $4.9 \mathrm{~m}$.

Nitrogen no longer constituted the limiting plant growth nutrient after the external restoration efforts. Typical values of the inorganic $\mathrm{N} /$ dissolved reactive $\mathrm{P}$ ratio before lake restoration measures are 3-5 (around the 1980's); in expost conditions (e.g. after nutrient diversion, wastewater treatment and in-lake treatment) the $\mathrm{N} / \mathrm{P}$ values are in the range of 13-15.

Table 4. Record of algal blooms in lake Varese over the last decades. Registro de floraciones algales en el lago Varese durante las últimas décadas.

\begin{tabular}{|c|c|c|c|c|c|}
\hline & 1979 & 1987-1988 & 1994 & 1999 & 2000 \\
\hline February & $\begin{array}{l}\text { Stephanodiscus } \\
\text { hantzschii }\end{array}$ & & $\begin{array}{l}\text { Cyclotella } \\
\text { ocelatta }\end{array}$ & $\begin{array}{l}\text { Asterionella } \\
\text { formosa }\end{array}$ & Chlorella sp. \\
\hline March & $\begin{array}{l}\text { Stephanodiscus } \\
\text { hantzschii }\end{array}$ & & $\begin{array}{l}\text { Rhodomonas } \\
\text { minuta }\end{array}$ & & \\
\hline April & $\begin{array}{l}\text { Rhodomonas } \\
\text { minuta }\end{array}$ & & & & \\
\hline May & $\begin{array}{l}\text { Sphaerocystis } \\
\text { schroeteri }\end{array}$ & $\begin{array}{l}\text { Clamydomonas sp. } \\
\text { Coelastrum } \\
\text { reticolatum } \\
\text { Scenedesmus } \\
\text { quadricaudata }\end{array}$ & $\begin{array}{l}\text { Asterionella } \\
\text { formosa }\end{array}$ & & \\
\hline June & & $\begin{array}{l}\text { Clamydomonas sp. } \\
\text { Coelastrum } \\
\text { reticolatum } \\
\text { Scenedesmus } \\
\text { quadricaudata }\end{array}$ & & & $\begin{array}{l}\text { Anabaena } \\
\text { flos-aquae }\end{array}$ \\
\hline July & $\begin{array}{l}\text { Mycrocystis } \\
\text { aeruginosa }\end{array}$ & $\begin{array}{l}\text { Microcystis } \\
\text { wesemberghii }\end{array}$ & Anabaena sp. & $\begin{array}{l}\text { Oscillatoria } \\
\text { limnetica }\end{array}$ & \\
\hline August & $\begin{array}{l}\text { Mycrocystis } \\
\text { aeruginosa }\end{array}$ & $\begin{array}{l}\text { Microcystis } \\
\text { wesemberghii }\end{array}$ & Anabaena sp. & $\begin{array}{l}\text { Oscillatoria } \\
\text { limnetica }\end{array}$ & \\
\hline September & $\begin{array}{l}\text { Oscillatoria } \\
\text { rubescens }\end{array}$ & $\begin{array}{l}\text { Microcystis } \\
\text { wesemberghii }\end{array}$ & Anabaena sp. & $\begin{array}{l}\text { Oscillatoria } \\
\text { limnetica }\end{array}$ & $\begin{array}{l}\text { Anabaena } \\
\text { flos-aquae }\end{array}$ \\
\hline October & $\begin{array}{l}\text { Mycrocystis } \\
\text { aeruginosa }\end{array}$ & & $\begin{array}{l}\text { Microcysti } \\
\text { flos-aquae }\end{array}$ & & \\
\hline November & & & $\begin{array}{l}\text { Microcystis } \\
\text { flos-aquae }\end{array}$ & & \\
\hline $\begin{array}{l}\text { Total } \\
\text { bloom number }\end{array}$ & 8 & 5 & 8 & 4 & 3 \\
\hline
\end{tabular}




\section{DISCUSSION}

In the 1970's it was believed that control of nutrient sources alone could lead to lake recovery as a general rule following the successes in deep lakes (e.g. Moss, 1989). Indeed, the initial restoration plan for the lake Varese was in line with this concept, where control of nutrient loading is achieved through the control of the nutrient point sources in the lake catchment. Soon it became apparent that the effects of a long history of eutrophication on lakes could not be fully reversed by nutrient reduction alone, due to a number of lake buffering mechanisms. Since that time, studies have identified $\mathrm{P}$ release from sediments to be a major factor constraining the recovery of shallow lake ecosystems after external loading have been controled (Phillips, 1977; Marsden, 1989; Sas, 1989; Jepersen et al., 1991; Rossi \& Premazzi, 1991; Pitt et al., 1997; Madgwick et al.,1999). The same mechanism can explain the results in lake Varese, where the internal loading has been presumed to be important, and even higher than the external loading (Rossi \& Premazzi, 1991; Premazzi, et al., 1995; Premazzi, 2002) and where after the maximum practicable external $\mathrm{P}$ loads control, only little changes in the lake quality had been witnessed.

In these lakes thus, direct interventions may have a key role in accelerating the restoration process and in controlling the effects on the lake's P release from sediments. Major in-lake eutrophication control methods include nutrient inactivation, dilution/flushing, hypolimnetic aeration, circulation, selective removal of hypolimnetic waters, lake level drawdown, covering bottom sediments, sediment removal (dredging), harvesting, and biological and chemical control (e.g. Ryding \& Rast, 1989). After a suitability and feasibility analysis of each of these techniques with the hydro-morphometric characteristics of lake Varese, hypolimnetic withdrawal and oxygenation were recommended in order to accelerate the lake response.

As a result, $9 \mathrm{t}$ of total $\mathrm{P}, 70 \mathrm{t}$ of total $\mathrm{N}$ and $55 \mathrm{t}$ of ammonia $\mathrm{N}$ have been removed from the lake in the years 2000/2001. DO concentration has always been maintained above $2-3 \mathrm{mg} \mathrm{O}_{2} / 1$ in the shallower sections. Lake transparency is now close to the final objective of the Regional Water Clean-Up Plan (i.e. 5m). Algal density has decreased by a factor of 4 and the frequency of algal blooms has decreased to half the frequency of the period ex-ante.

Nutrient loadings from lake Varese, due to the in-lake siphoning activities, did not significantly affect the total chemical load of lake Maggiore. It was estimated that the additional $\mathrm{P}$ and $\mathrm{N}$ loads represent about $2 \%$ and $0.5 \%$, respectively, of the total nutrient loads of lake Maggiore, calculated to be $180-183 \mathrm{t} \mathrm{P} / \mathrm{yr}$ and $9200-9900 \mathrm{t} \mathrm{N} / \mathrm{yr}$, largely included in the multi-annual variability and degree of uncertainty of any lake nutrient budget.

Moreover, the deep-water discharges have no significant negative impacts on downstream water systems, e.g. the Bardello River and the Maggiore Lake. The river water quality is influenced by the siphoning event only in the first stretch of the Bardello River (300-400 m out of $13 \mathrm{~km}$ total river length): the concentrations of unionised ammonia-nitrogen and sulphides never exceed the values considered harmful for aquatic life at the $\mathrm{pH}$ and temperature values registered.

Our approach in setting the final (and intermediate) restoration goals is based on the estimated natural background $\mathrm{P}$ level $\left(18 \mathrm{mg} / \mathrm{m}^{3}\right)$ from which an increase of $50 \%$ (and $100 \%$ ) is considered as a realistic target. The $\mathrm{P}$ concentration in lake Varese is decreasing at a rate of $20 \mathrm{mg} \mathrm{m}^{-3} \mathrm{y}^{-1}$. Thus, according to modelling predictions (Rossi, 1991; Premazzi, 1994) and to the MEI methodology (Vighi \& Chiaudani, $1985)$ the present $P$ level $\left(70 \mathrm{mg} / \mathrm{m}^{3}\right)$ is close to the intermediate objective for the lake. The final objective $\left(25-30 \mathrm{mg} / \mathrm{m}^{3}\right)$ would be attained after a few overturns (10-15 years) only through the implementation of the adopted in-lake measures (Rossi \& Premazzi, 1991).

The results obtained to demonstrate that the ultimate effect of the hypolimnetic withdrawal would translate in reducing the recovery time of lake Varese by half. 


\section{ACKNOWLEDGEMENTS}

The authors are thankful for the cooperation and participation of the Varese Province, which provided basic data and information, concerning the implementation and operation of watershed activities for sources' control.

Special recognition goes to the President of the Varese Province and members of the Environmental Department (Assessorato all'Ambiente) who provided essential support and constructive input to the project.

We would like to thank SOGEIVA S.A., the local company of the Varese Province, for providing invaluable information and advice about the operational activities of the wastewater treatment plant and the workings of in-lake measures.

\section{REFERENCES}

APHA. 1992. Standard methods for the examination of water and wastewater, $18^{\text {th }}$ ed. A.E. Greengerg, L.S. Clesceri, \& A.D., Eaton (eds). 815 pp.

CHIAUDANI, G. \& G. PREMAZZI. 1999. Chlorophyll determination: Methods in limnology, part 1. In: Manual for monitoring European lakes using remote sensing techniques. EUR Report 18665: 16-29. EN. Luxembourg Office of publication of European Communities.

IRSA. 1994. Metodi analitici per le acque. Quaderno $\mathrm{n}^{\mathrm{O}}$ 100. Istituto Poligrafico e Zecca dello Stato. 573 pp.

JEPPERSEN, E., P. KRISTENSEN, J. JENSEN, M. SØNDERGAARD, E. MORTENSEN \& A. LAURISDEN. 1991. Recovery resilience following a reduction in external phosphorus loading of shallow, eutrophic lakes: duration, regulating factors and methods for overcoming resilience. Memorie Istituto Italiano Idrobiologia, 48:127-148.

JIRKA, A. M. \& M. J. CARTER. 1975. COD determination. Analytical chemistry, 47(80): 1397.

MADGWICK, F. J. 1999. Restoring nutrient-enriched shallow lakes: integration of theory and practice in the Norfolk Broads, U.K. Hydrobiologia, 408/409: 1-12.

MARSDEN, M. W., 1989. Lake restoration by reducing external phosphorus loading: the influence of sediment phosphorus release. Freshw. Biol., 21: 139-162.

MOSS, B. 1989. Water pollution and the management of ecosystems: a case study of science and the scientist. In: Towards a more exact ecology. P.J. Grubb \& R.H. Whittaker (eds): 401-422. Thirtieth Symposium of the British Ecological Society. Blackwell Scientific, Oxford.

PHILLIPS, G. L. 1977. The mineral nutrient levels in three Norfolk Broads differing in trophic status, and an annual mineral content budget for one of them. Journal of Ecology, 65: 447-474.

PITT, J., A. KELLY \& G. L. PHILLIPS. 1997. Control of nutrient release from sediments. In: Restoration of the Norfolk Broads. F.J. Madgwick \& G.L Phillips (eds). Life 92-3/UK/031 and Broads Authority BARS 14. 98pp.

PREMAZZI, G. 1994. Piano di gestione e di controllo dei fenomeni di eutrofizzazione delle acque del lago di Varese. CCR- Ispra- Provincia di Varese (Contratto $\mathrm{n}^{\circ}$ 18597, 25 Agosto 1994). Relazione finale, November 1994.

PREMAZZI, G., G. CHIAUDANI, A. PEREIRA, C. CIGAINA, F. FARDINI, B. MILESI, E. RODARI \& G. ROSSI. 1995. Lago di Varese: Condizioni ambientali e soluzioni per il risanamento. EUR Report 16133 IT. Luxembourg, Office of Publication of European Communities, ISBN 92-826-8283-8.

PREMAZZI, G. 2002. Il risanamento del Lago di Varese: questi i risultati. Convegno Provincia Varese, 19. Aprile 2002.

ROSSI, G. 1991. Modelling lake pollution. EUR13998 EN. Luxembourg, Office of publication of European Communities. 142 pp.

ROSSI, G. \& G. PREMAZZI. 1991. Delay in lake recovery caused by internal loading. Water Research, 25(8): 567-575.

ROTT, E. 1981. Some results from phytoplankton counting intercalibration. Schweiz Z. Hydrol., 43: 34-62.

RYDING, S. O. \& W. RAST. 1989. The control of eutrophication in lakes and reservoirs. UNESCO.

SAS, H. 1989. Lake restoration by reduction of nutrient loadings: expectations, experiences, extrapolations. Academia Verlag Richarz, Sankt Augustin. 275 pp.

VIGHI, M. \& G. CHIAUDANI. 1985. A simple method to estimate lake phosphorus concentrations resulting from natural background loadings. Water Research, 19: 987-991. 
